\section{ÄLTEREN GERMANISTIK}

In Verbindung mit

J. A. Huisman, A.D. Kylstra, A. H. Touber,

P. Vermeyden und A.L. Vos

herausgegeben von

Cold Minis und Arend Quak

Band 15-1980

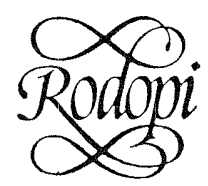

AMSTERDAM 1980
THE IMPORTANCE OF KINSHIP: UNCLE AND NEPHEW IN 'BEOWULF'*

by Rolf $\mathrm{H}$. Bremmer jr. - Nijmegen

1.0 In 1870 Johann Jakob Bachofen set out to work on a new edition of his 'Mutterrecht' 1 . This time he did not restrict himself anymore to the classical cultures, as in the first edition of his epochal study (1861), but looked for evidence of the state of matriarchy throughout the world. One of the fruits of his research was the observation that among many patriarchal peoples a special cordial relation existed between the mother's brother (MoBr) and the sister's son (SiSo). Bachofen published some of the results of his investigation in 1880 and 1886 in two slim volumes 'Antiquarische Briefe"2. Unfortunately, his results hardly found any resonance and have been completely neglected in subsequent anthropological research ${ }^{3}$. Only in 1924 did Arthur Radcliffe-Brown ${ }^{4}$ touch again upon the subject in detail. Although his explanation has been proved wrong and his representation of the facts was misleading 5 , he

* I would like to express my gratitude to Dr. Jan Bremmer, Dr. Joaquin Martinez Pizarro and T.A. Shippey for their considerable help in various ways.

1. On Bachofen and his 'Mutterrecht', see the 'Nachwort' of Karl Meuli in the edition of the 'Mutterrecht' in Johann Jakob Bachofens gesammelte Werke, Basel 1948, I-III; H.J.Heinrich ed., Materialen zu Bachofens 'Das Mutterrecht', Frankfurt/M. 1975.

2. Re-edited as volume 8 of the Gesammelte Werke, Basel/Stuttgart 1966.

3. See the 'Nachwort' by J.Dörmann in Gesammelte Werke VIII, 523-602.

4. A.Radcliffe-Brown, The Mother's Brother in South-Africa (South African Journal of Science 21/1924), 542-55 = idem, Structure and Function in Primitive Society (London 1952), pp. 15-31.

5. Cf. A.Kuper, Radcliffe-Brown, Junod and the Mother's Brother in Africa (Man 11/1976), pp. 111-5. 
greatly advanced upon Bachofen in that he discarded the evolutionary scheme in which the special relationship was considered as a survival of matrilineal times and looked for a solution in society as he found it. In this direction he has been followed by such scholars as Claude LéviStrauss $^{6}$, Jack Goody ${ }^{7}$ and Victor Turner $^{8}$ who have established that the mother's brother can develop a special relation with the sister's son, because he is an outsider in the paternal family and is not hindered by the patria potestas.

The discussion after Bachofen dealt mainly with African material, but recently it has been shown that the IndoEuropean peoples also knew a special cordial bond between the $\mathrm{MoBr}$ and the $\mathrm{SiSo}^{9}$. For the ancient Germans this was already observed by Tacitus who mentions that the sister's children are as dear to the $\mathrm{MoBr}$ as they are to the father. ${ }^{10}$ The relationship even became proverbial among the ancient Icelanders: móðurbróđrum verði menn likastir ${ }^{11}$. It is the aim of this essay to survey the evidence for this special relationship among the Anglo-Saxons and in particular to demonstrate its bearing on the interpretation of 'Beowulf'.

6. C.Lévi-Strauss, Structural Anthropology (Harmondsworth 1972), p. 42ff. (Translation of the French 1945 edition).

7. J.Goody, The Mother's Brother and the Sister's Son in West Africa (Journal of the Anthropological Society 89/1959),pp.61-88. 8. V. Turner, The Ritual Process (Harmondsworth 1974), pp.105-7. 9. J.Bremmer, Avunculate and Fosterage (Journal of Indo-European Studies 4/1976), pp.65-78, which includes an extensive bibliographical survey of the subject.

10. Germania, ed. J. Lindauer (Lateinische Literatur 12), Reinbek 1967, cap. 20:"Sororum filiis idem apud avunculum, qui ad patrem, honor. Quidem sanctiorem artioremque hunc nexum sanguinis arbitrantur et in accipiendis obsidibus magis exigunt, tamquam et animum firmius et domum latius teneant."

11. "May men resemble their mother's brothers most of all",Páls saga' in Biskupa sögur (Copenhagen 1858), I, p.134. (According to a pencil-note on the title page of the copy present in the Faculty Library, St Cross Building, Oxford, these sagas were edited by J. Sigurdsson and G. Vigfusson).
2.0 It has not escaped scholars that Beawulf stands in a special relationship to king Hygelac of the Geats 12 , but they have rarely gone beyond quoting this illustrative example of $\mathrm{MoBr}$ and SiSo in an Anglo-Saxon context. And yet quite a few instances of this bond are to be found in nonliterary works of the period. A survey of these instances will help the student to see that a literary work such as 'Beowulf' employs everyday notions, but also transfers them to a higher level.

2.1 After St. Augustine had successfully preached the Gospel in the kingdom of \#thelberht of Kent, he sent two bishops as missionaries to the kingdom of Essex ${ }^{13}$ : ". . . in qua videlicet gente tunc temporis Saberct nepos Aedilbercti ex sorore Ricula regnabat, quamvis sub potestate positus eiusdem Aedilbercti qui omnibus, ut supra dictum est, usque ad terminum Humbrae fluminis Anglorum gentibus imperabat". In the Old English version of Bede's 'History' this became ${ }^{14}$ :"In pære peode wæs in pa tid Sæberht cyning, Æઇelberhtes swustorsunu and his hera". The West-Saxon translator did not think it necessary to extol a Kentish king, but only mentioned the exact relationship between Athelberht and Sæberht. He even omitted the name of $Æ$ thelberht's sister, leaving full weight on swustorsunu. For the translator it was more important to state the nature of the relationship than to provide the name of Sæberht's mother.

12. E.g. F.B.Gummere, The Sister's Son (An English Miscellany Presented to Dr Furnivall) Oxford 1901, pp.137-8; F.Seebohm, Tribal Custom in Anglo-Saxon Law (London 1902), pp.68-9; E.Spolsky, Old English Kinship terms and 'Beowulf' (Neuphilologische Mitteilungen 78/1977), pp.233-8. An exception is N.E.Eliason, Beowulf, Wiglaf, and the Wægmundings (Anglo-Saxon England 7/1978), pp. 95-105, which appeared after I had finished this essay. Although there are some overlaps, Eliason's approach and application of the $\mathrm{MoBr}$ and SiSo relation is entirely different from mine.

13. Bede's Ecclesiastical History of the English People (=HE), eds. B.Colgrave and R.A.B.Mynors (Oxford 1969), II,3.

14. The Old English Version of Bede's Ecclesiastical History of the English People (=OEHE), ed. T.Miller (EETS OS 95) London 1890, II,3; cf. The Anglo-Saxon Chronicle (=ASC), I-II, ed. C.Plummer (Oxford 1896), MSS A and E sub anno 604. 
2.2 In the following passage Bede relates Oswald's succession to the Northumbrian throne after the death of king Edwin"15: "Erat autem nepos Edwini regis ex sorore Acha, dignumque fuit ut tantus praecessor talem habet de sua consanguinitate et religionis heredem et regni". In the Old English version of this passage we read:"Wæs he Oswald Eadwines nefa pæs æðelan cyninges, his sweoster sunu. Wæs pæt pæs wyrđe pæt swa æðele foregenga swilcne yrfeweard his æfæstnisse and his rices hæfde of his seolfes mægsibbe". Here again the name of the mother has been omitted.

2.3 Not only in secular, but also in spiritual circles a special place was reserved for the sister's son. The famous bishop Wilfrid, after having received a donation of land on the Isle of Wight from the West-Saxon king Cadwalla, took these measures before returning to the mainland ${ }^{16}$ : "At ipse partem quam accepit commendavit cuidam de clericis suis, cui nomen Bernvini, et erat filius sororis eius ..."Apart from the name of Wilfrid's nephew, this passage was faithfully rendered by the translator: "Ond he pe pone dæl, pe he onfeng, bebead sumum his preosta, pæs noma wæs Berhtwini, se wæs his sweostor sunu".

2.4 Another example of a MoBr and SiSo may be found in the 'Swein-episode' which took place during the reign of Edward the Confessor. Since the various manuscripts of the Anglo-Saxon Chronicle all give slightly different and sometimes incongruous information on the treacherous behaviour of Swein Godwinson, it is impossible to reconstruct exactly what happened in $1049^{17}$. Important for us is that a) one of the dramatis personae, Earl Beorn, is in two versions $(C, D)$ the companion of his $\mathrm{MoBr}$, Earl Godwin, and b) that after his violent death at the

15. HE III,6; OEHE III,6; Elfric's Lives of Saints, ed, W.W.Skeat (EETS OS 94/114) Oxford 1890-1900; reprinted as one volume 1966 , p. 126.

16. HE IV,6; OEHE II,6.

17. Plummer, ASC II, pp. 229-31 provides a convenient table in which the differences and the parallels are clearly brought out. hands of Swein's men, he is finally buried in Winchester with Cnut king his eam ${ }^{18}$.

2.5 In 1054 Earl Sigward of Northumbria successfully campaigned against the Scots though with considerable losses on the English side. The only casualities mentioned by name are his sunu Osbarn and his sweostor sunu Sihward, his namesake ${ }^{19}$.

2.6 Our next example in a way is Norman. However, it was taken down by an Anglo-Saxon scribe, some 13 years after the Conquest. Robert, eldest son of William the Conqueror, got involved in a serious dispute with his father concerning the former's claims on the Duchy of Normandy. Their relation deteriorated so dramatically that Robert fled to his eame Rotbryhte on Flandron ${ }^{20}$.

3.0 In the Anglo-Saxon laws ${ }^{21}$ there are no traces kept of a privileged position of the SiSo, not even where the payment or receiving of wergeld is concerned. In this respect Anglo-Saxon law differs from e.g. the Frisian tradition $^{22}$. Nevertheless some signs of a diverging practice as regards legacies may be found in Anglo-Saxon wills.

3.1 The first relative mentioned by bishop Theodred in his will is Osgot mine sustres sune. The second and third are Offe mine sustres sune and his broper. ${ }^{23}$

3.2 Elfeah ealdorman bequeathed his estate at Froxfield to Alfwine his swustur suna 24 .

3.3 In his will Archbishop Alfric showed himself to be very mindful of the church and its servants, although he

18. ASC MS C 1049, D 1050, E 1046

19. ASC MS D 1054.

20. ASC MS D 1079.

21. F. Liebermann, Die Gesetze der Angelsachsen, I-III, Halle 19031916.

22. "Alsa thi em eslein is, sa clagat thi sustersune and welle sin riucht hebba".(When the uncle (MoBr) has been killed, the sister's son complains and wants to have his due rights). Das Hunsingoer Recht, eds. W.J.Buma and W.Ebel (Altfriesische Rechtsquellen 4), Göttingen 1969, IX,20.

23. Anglo-Saxon Wills, ed. D.Whitelock (Cambridge 1930), no.I. (=ASW).

24. ASW, no. IX. 
did not leave any goods or lands to his brother, the abbot Leofric. It is remarkable that his estates in Gloucestershire he becwced his sweostrun and heora beornum. ${ }^{25}$

3.4 From the will of Ketel, a thane of Archbishop Stigand, it appears that he had a partnership with Eadwine min em and Wlfric min eam, regarding an estate at Mel$\operatorname{ton}^{26}$.

3.5 Abba geroefa declared in his will that after his death his property, would first of all go to his child, God willing, and his child's children. If God did not grant him any issue, then his wife should have it until the day she remarried. Then it was to be handed over to his brothers, but only in case they had any heirs. If not, a certain Freothumund was to become his heir. Should anything have happened to him in the meantime Jonne an ic minra swoestarsuna sucelcum se hit geðian wile and him gifede $b i \delta^{27}$. Here it is a long time before the sister's sons are mentioned, but they are not forgotten in the end.

4.0 In Anglo Saxon poetry apart from 'Beowulf', $\mathrm{MoBr}$ and SiSo are mentioned only twice, but it is important to notice that both mentions occur in a heroic, aristocratic setting and for that reason may point to the preservation of a traditional, cultural heritage.

4.1. Our first example takes the form of a riddle which conjures up a kind of West-Indian family picture ${ }^{28}$.

Wer sæt æt wine

ond his twegen suno

mid his wifum twam

swæse gesweostor ond hyra suno twegen,

25. ASW, no. XVIII.

26. ASW, no. XXXIV

27. Select English Historical Documents of the Ninth and Tenth Centuries, ed. F.E.Harmer (Cambridge 1914), no. II.

28. The Riddles of the Exeter Book, ed. F.Tupper Jr., (Boston 1910; repr. Darmstadt 1968), no. 47:“A man sat drinking wine with his two wives, and his two daughters - genuine sisters and their two sons, noble children; the father of each of the noble sons was there too, $\mathrm{MoBr}$ and nephew. All in all there were five lords and ladies sitting there".

freolice frumbearn; fæder wæs pær inne para æpelinga æghwæđeres mid,

eam ond nefa. Ealra wæron fife eorla ond idesa insittendra.

The answer to this riddle is Lot and his daughters, and the two sons he begot on his daughters 29 . The riddle employs one of the piquant episodes of the Bible $^{30}$ and it is somewhat surprising to find the results of an incestuous relation transformed into the kind of intellectual pastime the Anglo-Saxons were so fond of ${ }^{31}$. On the other hand it has recently been shown that part of the riddling technique depends heavily on taboos 32 . What is striking about the riddle is that $\mathrm{MoBr}$ and SiSo occur in the same half-line, thus indicating the two form a special pair. The episode of Lot, by the way, was not too much charged with taboo to be included in the biblical epic 'Genesis',33

4.2 In 'The Battle of Maldon'34, an early eleventh-century heroic poem, we are told of the fight of Earl Byrhtnoth of Essex against Viking marauders. The first victim of the Viking onslaught is Wulfmær:

Wund weard Wulfmær, wælræste geceas

Byrhtnodes mæg; he mid billum weard,

his swuster sunu, swide forheawan.

In a note on swuster sunu, Gordon ${ }^{35}$ has briefly drawn attention to the above-mentioned passage in Tacitus' 'Germania'. Dorothy Whitelock ${ }^{36}$, on the other hand, does

29. Riddles, pp. 178-9.

30. Genesis 19:30 38 .

31. C.L.Wrenn, A Study of Old English Literature (London 1967), p.60.

32. N.F.Barley, Structural Aspects of the Anglo-Saxon Riddle (Semiotica 10/1974), pp.143-75.

33. The Junius Manuscript, ed. G.Ph.Krapp (Anglo-Saxon Poetic Records I), New York/London 1931, 11. 2600-20.

34. The Anglo-Saxon Minor Poems, ed. E.V.K.Dobbie (ASPR IV), New York/London 1942, 11. 113-15.

35. The Battle of Maldon, ed. E.V.Gordon, (London 1937), p.51. 36. Sweet's Anglo-Saxon Reader, ed. D.Whitelock (Oxford 1975, rev.ed.), p.267. For Tacitus, see n. 10. 
not think it very probable that the Germanic tradition of Tacitus' days would still have been prevalent by the time of the poem's composition. The examples above are too telling, though, to be ignored and in fact they may help to throw some new light on the relation between uncles and nephews in 'Beowulf'.

5.0 There are two maxims in 'Beowulf'37 stressing the importance of kinship. After Beowulf on his return from Denmark had presented a golden torque and four horses to his uncle and lord, king Hygelac, the poet could not refrain from delivering a pithy sermon on this gesture of Beowulf's:

neallys inwitnet

dyrnum cræfte,

hondgesteallan.
$2166^{\mathrm{a}}-69^{\mathrm{a}}$
From this

Swa sceal mæg don, ođrum bregdon deað renian the particular ${ }^{38}$, and states that Beowulf lived up to this moral standard:

$$
\begin{aligned}
& \text { Hygelac wæs, } \\
& \text { niða heardum, } \\
& \text { ond gehwæa swyðe hold, } \\
& \text { hropra gemyndig. }
\end{aligned}
$$$$
2169^{b}-71
$$

5.2 There is a distinct echo of the above maxim when one of Hrothgar's retainers recites the Lay of Sigemund. There it is said that Sigemund experienced many strange adventures, and that he took part in feuds and violent crimes of which people did not know a thing:

ponne he swylces hwæt secgan wolde,

eam his nefan, swa hie a wæron

æt niða gehwam nydgesteallan. $879^{\mathrm{b}}$ - 82 Beowulf and Hygelac, as well as Fitela and Sigemund,

37. All quotations are from: Beowulf and the Fight at Finnsburh, ed. F.Klaeber, (Boston 1950, 3rd ed.). The punctuation has sometimes been slightly altered, however.

38. N.F.Barley, A Structural Approach to the Proverb and Maxim with Special Reference to the Anglo-Saxon Corpus (Proverbium 20/1972), pp.737-50. form an ideal pair in the eyes of the poet. The members of each pair stand in the relation of SiSo and $\mathrm{MoBr}$ to each other. It has been argued ${ }^{39}$ that for reasons of Christian morality the poet wanted to conceal the nature of the relationship between Sigemund and Fitela as the 'Volsungasaga 40 has it. According to this tradition Sigmundr (= OE Sigemund) begot Sinfjętli (=OE Fitela) on his sister Signý, so that he was both Sinfjotli's father and his uncle $(\mathrm{MoBr})$. It is doubtful whether the Icelandic tradition was also known to the Anglo-Saxons. In

'Beowulf', e.g., Sigemund is the dragon killer, whereas in the 'Volsungasaga' this part is played by his son Sigurdr. Apart from this, the fact that another incestuous relationship was turned into a riddle and also included in the OE 'Genesis' (see 4.1) does not indicate any bashfulness on the part of Anglo-Saxon poets to treat such delicate matters as incest. We are left with the fact that in 'Beowulf' Fitela is Sigemund's only confidant and their intimate relationship is expressed in just one halfline: eam his nefan.

5.3 Certain characters in 'Beowulf' are not identified through their fathers, but through their uncles. In the introduction of part II of the poem (lines 2200 onwards) we get a brief sketch of the new political situation in Geatland, after Hygelac had perished on the Frisian battlefield:
... ond Heardrede
under bordhreođan
đa hyne gesohtan
hearde hildfrecan,
niđa genægdan
hildemecas
to bonan wurdon,
on sigepeode
Heađo-Scilfingas,
nefan Hererices.

Even before Heardred is identified as the son of Hygelac (line 2386), he is introduced to us as Hereric's nephew.

This Hereric cannot be anyone else but the brother of

39. Klaeber, p. 159; O.Höfler, Kultische Geheimbünde der Germanen (Frankfurt/M. 1934), p. 213.

40. The Saga of the Volsungs, ed. R.G.Finch, (London 1965),

chap. 7. 
Heardred's mother, Queen Hygd, daughter of Hæreth (line 1929) ${ }^{41}$.

5.4. In the first of three allusions to Hygelac's fatal expedition to the Frisians, which is made after Queen Wealhpeow has presented a precious ring to Beowulf, the poet informs us that:

pone hring hæfde Hygelac Geata,

nefa Swertinges nyhstan side,

sypðan he under segne sinc ealgode,

wælræf werede; 1202-5

Here again, no identification through the paternal, but through the maternal line. There can be little doubt that Hygelac was related to Swerting through his mother. If it were not for historical reasons ${ }^{42}$, then for the traditional Germanic principle of name-giving which required alliterating names within the family ${ }^{43}$. So Swerting must have been Hygelac's $\mathrm{MoBr}$, or mother's father $(=\mathrm{MoFa})$, though the poet does not explicitly say so ${ }^{44}$.

41. It has been F.Seebohm's merit (see n.12) to have first drawn attention to Hereric as Heardred's MoBr. It is therefore surprising to find that both Klaeber, p. 437 and C.L.Wrenn, Beowulf and the Finnsburg Fragment, rev. by W.F.Bolton, (London 1973, 3rd ed.),

p. 297 still express their doubts as to the identification of Hereric.

Whether this Hereric should be connected with the Burgundian king Hereric, father of the Germanic heroine Hildegund in the Walter legends, should be viewed with some scepticism, cf. H.Schneider, Germanische Heldensagen, II,3, (Berlin/Leipzig 1934), pp.49-50.

42. See K. Malone, Swerting (Germanic Review 14/1939), pp.235-57. 43. A quick glance at the genealogical table of the Geatish dynasty will reveal that this rule was strictly applied by Hræthel and his descendants:

\begin{tabular}{lll} 
& Hræthel & \\
\hline Herebeald & Hæthcyn & Hygelac \\
& & Heardred
\end{tabular}

44. I find little credibility in J.Hoops' comment in his Kommentar zum Beowulf (Heidelberg 1932), p. 151 that:"ein altgermanischer Held wurde nach dem Tod seines Vaters gern als der Neffe seines mütterlichen Oheims bezeichnet". In my opinion he wrongly inferred this from Seebohm's remark (n.12), p.69 on Swerting. On the position of the MoFa, see Bremmer (n.9), p. 72.
5.5 The next nephew presents a somewhat difficult case, since here we have to do with a textual emendation. In the Offa-episode we read that:

ponon Eomer woc

hæledum to helpe, Hemminges mæg,

nefa Garmundes, niða cræftig. $\quad 1960^{\mathrm{b}}-2$

For Eomer the MS reads geomor, but in order to restore the alliteration Thorpe proposed to emend this to Eomer, a suggestion followed by most editors 45 .

5.5.1 What was the exact relationship between Hemming, Offa, Eomer, and Garmund? Clearly there are some difficulties involved. Only two of the four names alliterate, which makes it hard to construct a genealogical table 46 . With the help of Mercian genealogies various scholars have attempted to give some shape to this jumble of names. For our present purpose Hemming can be left aside, and attention will be focused on Garmund and Eomer. Klaeber $^{47}$ calls Garmund 'father of the Angle king Offa', without adducing any supporting evidence. Wrenn 48 does the same, but refers to the Mercian genealogies. There the order is: Wermund - Offa - Angengeot - Eomer ${ }^{49}$. The Garmund from 'Beowulf' is equated with Wermund and MS geomor with Eomer/Eomær, so that in 'Beowulf' Eomer becomes the grandson of Garmund. Malone $\mathrm{5}^{50}$

45. Beowulf and Judith, ed. E.V.K.Dobbie (ASPR IV), London 1954, p. 217; Klaeber, ad loc; Wrenn (n. 41), ad loc.; K. Sisam, Notes on Old English Poetry (Review of English Studies 22/1946), pp.263-64. 46. Compare for instance the table as given in Hoops (n.44), p.333, with the one in Beowulf, II, eds. M.Heyne and L.L.Schücking, rev. by E.von Schaubert, (Paderborn 1963, 18th ed.); Klaeber, p.199: "Was Hemming a brother of Garmund? Or Garmund's (or Offa's) father-in-law?"

47. Klaeber, p. 435.

48. Wrenn (n.41), p. 295.

49. There are four traditions: MS Cotton Vespasian B VI: Uermund - Offa - Angengeot - Eamer; MS CCCC 183: Wærmund - Offa Angengiot - Eomær; MS Harley 3859: Guermund - Offa - Ongen - Eamer; MS Cotton Tib. A VI: Wærmund - Offa - Angelpeow Eomær. See R.W.Chambers, Beowulf: An Introduction (Cambridge 1959, 3rd ed.), pp. 197-98.

50. Swerting (n.42), p. 235. 
even prefers to make Eomer the great-grandson of Garmund - which strictly speaking is the only logical out come of applying the Mercian genealogies to the poem. If his suggestion were true, we would have a unique instance of nefa 'great-grandson'. 51

Relying on the principle of name-giving, the conclusion seems inescapable that Eomer is related to Garmund through his sister Modthryth and most possibly is his SiSo or possibly his daughter's son $(=\mathrm{DaSo}) .{ }^{52}$. This conclusion does not necessarily conflict with the Mercian list of kings 53 . Neither would it be the first time for a man to have succeeded his $\mathrm{MoBr}$ to the throne ${ }^{54}$.

5.5.2 An additional argument for the conclusion that Garmund is Eomer's MoBr (or MoFa) seems to present itself from the formulaic ring of line 1962: nefa Garmundes, nida creftig. Parallels in which nefa 'SiSo' occurs along with a form of nid 'battle' can be found in lines 2170 and 2206, while in lines 881-2 the two words are separated only by a half-line. This is no coincidence since within as well as outside the poem we have evidence that

51. See L.Lancaster, Kinship in Anglo-Saxon Society, I-II, (British Journal of Sociology 9/1958), pp. 230-50 and 359-77; esp. pp.236237. Hoops, Kommentar (n.44), p. 216, is well aware of the difficulties implied here and remarks on nefa 1961: "Hier wohl 'Enkel', lat. nepos; sonst im Beow. 'Neffe', so $881,2170,2206$; zweifelhaft 1203."

52. Women seem to have sometimes escaped the alliterative family names, cf. Freawaru, daughter of king Hrothgar.

53. "It is not uncommon to find relationships varying in different versions of a sage", E.Rickert, The Old English Offa Saga (Modern Philology 2/1904), pp.28-76; esp. p.28 and n.5. Cf. Kenneth Sisam's remark on the ancestry of the Burgundian king Gundobad and English heroic poetry in Anglo-Saxon Royal Genealogies (Proceedings of the British Academy 39/1953), pp. 287-348; esp. 323.

54. See 2.2 above. Cf. A.W.Aron, Traces of Matriarchy in Germanic Hero-lore (University of Wisconsin Studies in Languages and Literature, IX, Madison 1920), pp.5-6. Also, it can hardly be coincidence that Professor J.R.R.Tolkien has Theoden, king of the "Germanic" Rohirrim, foster his SiSo Eomer (!) who eventually succeeds him to the throne. See The Return of the King, being the third part of The Lord of the Rings (London 1955), p. 351.
$\mathrm{MoBr}$ and SiSo went to battle as comrades 55 .

5.5.3 The fact that not ten lines after the nefa Garmundes we come across the poet's description of the affectionate reunion between Hygelac and Beowulf (lines 1970ff.), contributes to the interpretation in line 1962 of nefa 'SiSo'.

5.6 We have shown that in Anglo-Saxon society the cordial bond between $\mathrm{MoBr}$ and SiSo was a reality. It is now perhaps easier for us to understand the grief of Hildeburh in the Finnsburh-episode. Of course, all critics agree that the loss of her brother and her - unnamed - son as a result of one and the same fight was the cause of infinite affliction on the part of Hildeburh. Although we are not told how the Dane Hnæf and his SiSo fall in the battle, critics have usually assumed that they were fighting on different sides, but there is no indication whatsoever in the text for this assumption. The probability should not be dismissed therefore, that Hildeburh's son was a member of Hnæf's comitatus. The latter case would have placed him into the popular heroic theme of a father versus son confrontation. For the outcome this is not important, however, if we notice how Hildeburh's grief is expressed:
beloren leofum
bearnum ond broðrum; hie on gebyrd hruron
gare wunden: pæt wæs geomoru ides! $1072^{b}-5$
This characteristic Old English exclamatory sentence follows almost immediately upon the mention of son and brother and the thought it expresses recurs after Hildeburh has commanded that her son be laid on the funeral pyre:

55. See 2.4, 2.5, 4.2 above. Hondgestealla, lindgestealla (lines 2169, 1973): Hygelac and Beowulf; nydgesteallan (line 882): Sigemund and Fitela. 
eame ${ }^{56}$ on eaxle. Ides gnornode,

geomrode giddum.

$1117-8^{\mathrm{a}}$

Indeed, what can be more grievous than a $\mathrm{MoBr}$ and a SiSo on the pyre? To watch what should and could have been an ideal pair - were it not for treachery being consumed by flames? 57

6.0 Thus far I have mentioned one of the two maxims on kinship in 'Beowulf' (see 5.0). The other one is used when in Part II king Beowulf is fighting the dragon and his twelve companions see their lord is losing ground:

Nealles him on heape handgesteallan,

æđelinga bearn ymbe gestodon

hyldecystum, ac on holt bugon,

ealdre burgan. $2596-9^{b}$

$\mathrm{He}$ is forsaken by his comrades, but masterfully the poet gives a sudden turn to this deplorable and shameful situation:

$$
\begin{aligned}
& \text { sefa wid sorgum: } \\
& \text { Hiora in anum weoll } \\
& \text { sibb' æfre ne mæg } \\
& \text { wiht onwendan pam pe wel penced } \\
& 2599^{\mathrm{b}}-2601
\end{aligned}
$$

Immediately after this maxim Wiglaf enters the picture (line 2602), so that we get the following sequence: Beowulf is deserted by his comrades (handgesteallan), one of them holds back through sympathy with the solitary warrior, a maxim on kinship, and the introduction of Wiglaf. Even though it is not stated explicitly, we are to conclude from this that Wiglaf is Beowulf's kinsman who performs the duty of supporting his comrade in battle (see 5.5.2).

56. The MS reads earme, but Holthausen's emendation is usually accepted nowadays, see Dobbie, ASPR IV, pp.175-76 and Wrenn, Beowulf, p. 140. In favour of earme are e.g. Heyne/Schücking, Beowulf pp.117-18 and Beowulf und die kleineren Denkmäler der Waldere und Finnsburg, eds. J.Klegraf, W.Kühlwein, D.Nehls, and R.Zimmermann (Heidelberg 1976), I. pp. 120-21. It goes without saying that eame suits my argument better than earme.

57. For a SiSo buried with his $\mathrm{MoBr}$, see 2.4 above.
Further on in the poem, after they have together killed the dragon, their relationship is expressly referred to: Feond gefyldan - ferh ellen wræc ond hi hyne pa begen abroten hæfdon, sibæđelingas. $2706-8^{\mathrm{a}}$

Two kinsmen fighting side by side triggers yet another maxim:

$$
\begin{aligned}
& \text { Swylce sceolde secg wesan, pegn at pearfe! } \\
& 2708^{\mathrm{b}}-9^{\mathrm{a}}
\end{aligned}
$$

6.1.2 However bravely Wiglaf has assisted his lord and kinsman in the dragon-fight, Beowulf is mortally wounded, but still has time to bequeath his war-gear to Wiglaf (lines 2809-16). His motives are noteworthy:
$\mathrm{Nu}$ ic suna minum syldan wolde
guđgewæむu,
pær me gifeđe swa
ænig yrfeweard æfter wurde

lice gelenge.

$2729-32^{\mathrm{a}}$

Since this is not the case, Wiglaf takes the place of a son and diligently fulfils one of Beowulf's last wishes by fetching some of the most precious items from the dragon's hoard (lines $2743 \mathrm{ff}$ ). After the hero has breathed his last, we get a moving picture of Wiglaf trying to revive his lord and kinsman:

$$
\begin{aligned}
& \text { He gewergad sæt, } \\
& \text { feđecempa frean eaxlum neah, } \\
& \text { wehte hyne wætre; him wiht ne speow. } \\
&
\end{aligned}
$$

It might seem far-fetched to call to mind that scene in the Finnsburh-episode where Hildeburh watches her son lying on the pyre eame on eaxle, but the poet's diction is almost the same: frean eaxlum neah; and so is the situation: the ties of blood broken by a violent death. 6.1.3 In his farewell-speeches Beowulf has given Wiglaf full instructions as to the fundral (lines 2802-8). Wiglaf, so to say, becomes the executor of Beowulf's will, and indeed carries out his lord's instructions with authority. Although the epic ends with the funeral rites performed for Beowulf and a last ode to him by the poet, it does not seem adventurous to assume that Wiglaf, as the last 
member of the Wægmunding clan (lines 2813-4 ${ }_{58}^{\mathrm{a}}$, succeeds his kinsman to the throne ${ }^{58}$.

7.0 The Indications enumerated in 6.1 .3 all point to the conclusion that Beowulf is Wiglaf's maternal uncle, or, in other words, that Wiglaf is the son of a sister of Beowulf's, even though such a sister is not mentioned in the poem. The following genealogical table may serve to illustrate this conclusion $^{59}$.

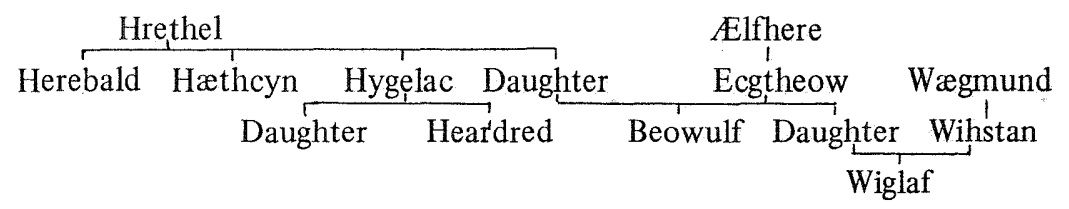

This table has the advantage that for all persons involved the alliteration is secured ${ }^{60}$. Wild noticed that this table places Wiglaf in the same relation to Beowulf as Hildeburh's son to Hnæf and Fitela to Sigemund, offering at the same time a plausible explanation for the poet's not mentioning Beowulf's sister at all ${ }^{61}$. Unfortunately, he did not dig into the matter more deeply.

8.0 Now one may wonder - and rightly so - why it is so important to establish such a relationship between Beowulf and Wiglaf? In my opinion the bond between $\mathrm{MoBr}$ and SiSo functions in the poem as a mirror to the bond between father's brother $(=\mathrm{FaBr})$ and brother's son $(=\mathrm{BrSo})$. The one is always positive, the other is troubled ${ }^{62}$.

58. After I myself had inferred this from the poem, I was pleasantly surprised that D.R.Barnes, Folktale Morphology and the Structure of Beowulf (Speculum 45/1970), pp. 416-34 arrives at the same conclusion on p. 431 by applying V.Propp's theory of folktale morphology to the poem. See also note 54 .

59. F. Wild, Beowulf und die Wægmundinge (Moderne Sprachen Schriftenreihe VI, Wien 1961), p. 19.

60 . For the exceptional case of Beowulf, see Klaeber, Beowulf, p. xxvii.

61. Beowulf und die Wægmundinge, p. 20.

62. For strife between $\mathrm{FaBr}$ and $\mathrm{BrSo}$, see Bremmer (n.9), p. 68; K.F.Drew, The Lombard Laws (Philadelphia 1973), pp. 79-80; HE III,14; HE III,24; ASC 887 MSS A and E; ASC 901 MSS A and D;
8.1 The rebellion of Eanmund and Eadgils against their FaBr Onela, king of the Swedes (lines $2379^{b}-97 ; 2611-9$ ), is the reverse of Wiglaf's attitude towards Beowulf. Nor does Onela care very much for his BrSo: the sword which was Eanmund's was presented by him to the young prince's slayer Wihstan, Wiglaf's father. The poet bitterly comments upon this gesture:

peah pa he his brođor bearn

no ymbe ða fæhðe spræc, abredwade.

$$
2618^{\mathrm{b}}-9
$$

This precious sword with an infamous history focuses our attention on Wiglaf once more (line 2620) who comes to the rescue of his kinsman and helps him kill the dragon with this very sword. Wiglaf and Beowulf address each other with terms of endearment: Leofa Beowulf (line $2663^{\mathrm{a}}$ ) and Wiglaf leofa (line 2745). Onela, on the other hand, chases his nephews from his realm, but is eventually killed by his BrSo Eadgils (lines 2391ff).

8.2 Another quarrel between $\mathrm{FaBr}$ and $\mathrm{BrSo}$, though treated in a rather allusive way, is that between Hrothgar and Hrothulf. Immediately after the Finnsburh-episode, where we have witnessed the tragedy of Hildeburh's loss of brother and son, we read:

Pa cwom Wealhpeow ford

gan under guldnum beage pær pa godan twegen sæton suhtergefæderan: pa gyt wæs hiera sib at-

$$
\text { æghwylc oðrum trywe. } \quad 1162^{\mathrm{b}}-5^{\mathrm{a}}
$$$$
\text { gædere, }
$$

Shortly before the scop sang his Lay of Finnsburh, we had come across Hrothgar and Hrothulf drinking gladly together:

$$
\text { nalles facenstafas }
$$

Anglo-Saxon Charters, ed. A.J.Robertson (Cambridge 1950, 2nd ed.), no. LXIII. In the otherwise rather dry charters, this so-called Brabourne charter suddenly comes to life:"The epic ingredients are there in earthy mould, Hrothulf and Hrethric in the home-counties", H.R.Loyn, Kinship in Anglo-Saxon England (ASE 3/1974), pp. 197-209; esp. p. 202. 
Eeod-Scyldingas pendon fremedon

$$
1018^{\mathrm{b}}-9
$$

Moreover, in queen Wealhtheow's speech to Hrothgar (lines 1169-80) the hope is expressed that Hrothulf will behave as a friend towards the sons of his $\mathrm{FaBr}$ Hrothgar. It is generally agreed ${ }^{63}$ that these passages allude to the future treachery of Hrothulf as we know it from Scandinavian sources $^{64}$. There his behaviour is the exact opposite of what Wealhtheow had hoped for.

9.0 In our discussion we have shown from internal evidence, corroborated by external evidence, that the relation $\mathrm{MoBr}$-SiSo plays a significant role in 'Beowulf', either by way of allusion: Swerting - Hygelac, Hereric - Heardred, Garmund - Eomer (?); or through emphasis: Hygelac - Beowulf, Sigemund - Fitela, Hnæf - Hildeburh's son. Both by analogy and through indications from the text, it is decided that Beowulf is the maternal uncle of Wiglaf.

On the other hand, we have seen that the $\mathrm{FaBr}-\mathrm{BrSo}$ relation (Hrothgar - Hrothulf, Onela - Eanmund and Eadgils) is the reverse of the MoBr-SiSo bond.

Whether the poet devised this antithesis on purpose is a question difficult to answer, but I am inclined to answer it in the positive. It gives us a better insight into both the joys and the tragedies of the heroic society as it is depicted in 'Beowulf'.

63. See e.g. Klaeber, Beowulf, p. xxxii; Wrenn, Beowulf, p. 68; D. Whitelock, The Audience of Beowulf (Oxford 1951), pp. 35-37; T. A.Shippey, Old English Verse (London 1972), p. 31. For an opposite view, see K. Sisam, The Structure of Beowulf (Oxford 1965), pp. $80-82$.

64. Chambers (n. 49), p. 26. 